\title{
Association of Obesity and C-Reactive Protein with Coronary Artery Disease
}

\author{
Mohsin Ahmed ${ }^{1}$, Md. Mesbahul Islam², AKM Monwarul Islam³, Mohammad Arifur Rahman ${ }^{4}$ Kazi Abul Fazal \\ Ferdous $^{5}$, CM Khudrate-E-Khuda ${ }^{6}$, Bikash Chandra Das ${ }^{7}$, Mohammad Nizam Uddin $^{8}$
}

\begin{abstract}
:
Background: Obesity is now becoming a global epidemic. It is most of the times associated with hypertension, diabetes mellitus (DM), metabolic syndrome and dyslipidemia which are known risk factors for coronary artery disease (CAD). Coronary arteriosclerosis comprises a series of inflammatory responses at cellular and molecular level, whose reactions are stronger in obese patients. The objective of this study was to observe the association of obesity and raised inflammatory markers with CAD.

Method: This cross-sectional study was carried out in the Department of Cardiology, Dhaka Medical College Hospital, Dhaka, Bangladesh, involving 668 patients of ischemic heart disease who underwent coronary angiography (CAG) from January 2017 to December 2017. Obesity was defined as body-mass index (BMI) $\geq 30.0$ $\mathrm{kg} / \mathrm{m}^{2}$. C-reactive protein (CRP) was measured as the inflammatory marker, and was considered as high if $>10$ $\mathrm{mg} / \mathrm{L}$. CAD was classified on the basis of CAG findings: insignificant if stenosis is $\mathbf{5 0 0 \%}$ and significant if stenosis is $\geq 50 \%$; and single-vessel, double-vessel, triple-vessel disease and normal coronaries according to number of vessels involved. Chi square test was used to analyze the categorical variables, and Pearson's correlation coefficient was used to test the relationship between CRP and BMI in CAD patients. $p$ values of $<0.05$ were considered as statistically significant.
\end{abstract}

Results: Demographic characteristics like age, sex and educational status did not differ significantly between obese and non-obese patients. Risk factors for CAD were similar between obese and non-obese, as well as, between high-CRP ( $>10 \mathrm{mg} / \mathrm{L})$ and non-high CRP ( $\leq 10$ $\mathrm{mg} / \mathrm{L}$ ) groups, however, DM, hypertension and dyslipidaemia were significantly more common in obese and high-CRP groups than in non-obese and non-high CRP groups. Raised CRP was significantly more common in obese than in non-obese patients $(56.9 \%$ vs. $47.9 \%$, $p=0.04)$. Significant positive correlation was found between CRP and BMI ( $r=0.228 ; p=0.001)$. Triple-vessel CAD was found significantly more commonly in obese group than in non-obese group $(29.3 \%$ vs $24.4 \%$, $p=0.04)$, whereas normal coronaries were more common in nonobese than in obese counterpart. Obesity, high CRP (>10 $\mathrm{mg} / \mathrm{L})$, DM, and high $\mathrm{HbA1c}(\geq 6.5 \%)$ were found significant predictors of severe CAD $(p<0.5)$ in multivariate logistic regression analysis.

Conclusion: Obesity is associated with raised inflammatory marker in patients with CAD, and a significant positive association exists between obesity and inflammation and CAD. Future studies are needed to explore the impact of type of obesity and inflammation on CAD.

Keywords: Obesity, Body Mass Index, Inflammation, CReactive Protein, Coronary Artery Disease.

1. Associate Professor, Department of Cardiology, National Institute of Cardiovascular Diseases, Dhaka, Bangladesh

2. Assistant Professor, Department of Cardiology, Anwer Khan Modern Medical College \& Hospital, Dhaka, Bangladesh

3. Associate Professor, Department of Cardiology, National Institute of Cardiovascular Diseases, Dhaka, Bangladesh

4. Junior Consultant, Department of Cardiology, Sarkari Karmachari Hospital, Dhaka, Bangladesh

5. Medical Officer, Department of Cardiology, Dhaka Medical College, Dhaka, Bangladesh

6. Assistant Professor, Department of Cardiology, National Institute of Cardiovascular Diseases, Dhaka, Bangladesh

7. Registrar, Department of Cardiology, Dhaka Medical College, Dhaka, Bangladesh

8. Junior Consultant, Department of Cardiology, Dhaka Medical College, Dhaka, Bangladesh

Address of Correspondence: Dr. Mohsin Ahmed, Associate Professor, Department of Cardiology, National Institute of Cardiovascular Diseases, Dhaka, Bangladesh. Email: mohsinsohel07@gmail.com.

DOI: https://doi.org/10.3329/bhj.v36i1.55512

Copyright $\odot 2017$ Bangladesh Cardiac Society. Published by Bangladesh Cardiac Society. This is an Open Access articles published under the Creative Commons Attribution-NonCommercial 4.0 International License (CC BY-NC). This license permits use, distribution and reproduction in any medium, provided the original work is properly cited and is not used for commercial purposes. 


\section{Introduction:}

Ischaemic heart disease (IHD) or coronary artery disease (CAD) is an important cause of mortality and morbidity of Mankind, and is the leading cause of death over decades. ${ }^{1,2}$ IHD affects around 126 million individuals $(1,655$ per 100,000$)$, which is approximately $1.72 \%$ of the world's population. The current prevalence rate of IHD has been estimated to be 1,655 per 100,000 population is expected to exceed 1,845 by the year $2030 .{ }^{1}$ Nine million deaths are caused by IHD globally. ${ }^{1}$ On the other hand, IHD is the biggest killer, and accounts for $16 \%$ of the world's total deaths. ${ }^{3}$ Since 2000 , the largest increase in deaths has been for this disease, rising by more than 2 million to 8.9 million deaths in $2019 .^{3} \mathrm{~A}$ number of risk factors are now known to be associated with IHD, including diabetes mellitus (DM), hypertension, smoking, hyperlipidemia, obesity, homocystinuria, and psychosocial stress. ${ }^{4}$ Among these, obesity is common, an important public health issue, and is currently considered as a global epidemic. ${ }^{5}$ Its magnitude is on the rise. According to a systematic review of prevalence of overweight and obesity in children and adults during 1980-2013, the situation has worsened significantly in adults, as well as, in children, in developed, as well as, in developing countries. ${ }^{6}$ Worldwide, the proportion of adults with a body-mass index (BMI) of $\geq 25 \mathrm{~kg} / \mathrm{m} 2$ increased between 1980 and 2013 from $28.8 \%$ to $36.9 \%$ in men, and from $29.8 \%$ to $38.0 \%$ in women. Prevalence has increased substantially in children and adolescents in developed countries; $23.8 \%$ of boys and $22.6 \%$ of girls were overweight or obese in 2013. The prevalence of overweight and obesity has also increased in children and adolescents in developing countries, from $8.1 \%$ to $12.9 \%$ in 2013 for boys and from $8 \cdot 4 \%$ to $13.4 \%$ in girls.

Obesity is now considered an independent risk factor of CAD. ${ }^{7}$ The interplay between obesity, inflammation and CAD is complex, but important in the pathophysiology of CAD. Adipose tissue was traditionally thought to be metabolically inert, however, it is now known that fat, specially the abdominal fat is a highly active endocrine and paracrine organ It also secrets a number of biological molecules including the inflammatory mediators. ${ }^{8}$ The proinflammatory cytokines released from the visceral fat of obese persons, e.g., tumor necrosis factor-alpha (TNFalpha), interleukin-6 (IL-6), leptin and visfatin have a potential of causing atherosclerosis. ${ }^{9}$ In obese individuals, macrophages first accumulate within the adipose tissue, leading to local inflammation. As the obesity increases, proinflammatory factors, including IL1, IL-6 and TNF- \pm , are produced in the adipose tissue. Macrophage accumulation and the subsequent local inflammation result in systemic inflammation. Endothelial dysfunction occurs during the early stages of atherosclerosis and is responsible for the pathophysiological changes in subclinical atherosclerosis, which include changes in a variety of mediators, surface proteins, and in autacoids that are involved in vasomotion, coagulation and inflammation. ${ }^{10-}$ 2 Obesity also can increase systemic oxidative stress independently of blood glucose and diabetes. ${ }^{11}$ The association between obesity and clinically significant CAD is blatant in the Framingham Heart Study ${ }^{13}$ and the Nurses' Health Study ${ }^{14}$. Each unit of change in BMI was associated with $9 \%$ increase in ischemic cardiac events in the Asia Pacific Cohort Studies Collaboration. ${ }^{15}$

C-reactive protein (CRP) is an acute-phase reactant, and also is one of the strongest markers of chronic inflammation. Besides diagnostic potential, it appears to have significant role in the aetiopathogenesis of coronary atherosclerosis. ${ }^{16}$ More than 20 prospective epidemiologic studies have demonstrated that highsensitivity CRP is an independent predictor of myocardial infarction, stroke, peripheral arterial disease, and sudden cardiac death, even in apparently healthy individuals ${ }^{17,18}$ On the other hand, CRP mRNA has been shown to be expressed in human adipose tissue, indicating that adipose tissue may be an important source of circulating CRP. ${ }^{19}$ Two recent studies have demonstrated that exercise training in conjunction with weight reduction significantly affected the CRP levels, body composition, and human left ventricular growth. ${ }^{20,21}$

Both CAD and obesity are common public health issues in Bangladesh. Like other South Asians, Bangladeshis appear unduly prone to develop CAD, which is often premature in onset, follows a rapidly progressive course and angiographically more severe. ${ }^{22}$ On the other hand, according to the 2011 Bangladesh Demographic and Health Survey, the prevalence of overweight and obesity in adults aged $35-70$ years was $18.9 \%$ (male $17.4 \%$ and female $18.4 \%$ ) and $4.6 \%$ (male $3.0 \%$ and female $6.0 \%$ ) respectively. ${ }^{23}$ Like many other aspects, the relationship between obesity, inflammation and CAD in Bangladeshi ethnicity has not been adequately studied.

\section{Methods:}

This cross-sectional study was carried out in the Department of Cardiology, Dhaka Medical College Hospital, Dhaka, Bangladesh, involving 668 patients of ischemic heart disease who underwent coronary angiography (CAG) from January 2017 to December 2017. Patients with infections, connective tissue disease and trauma were excluded. Also, patients with secondary 
obesity like hypothyroidism were excluded. The patients' demographic variables, such as age, sex, waist and hip circumferences were recorded, and body-mass index (BMI) was calculated. BMI of $\geq 30.0 \mathrm{~kg} / \mathrm{m}^{2}$ was considered as obese. ${ }^{24}$ Blood samples were collected for investigation before CAG. In this study, CRP was measured to assess inflammatory activity. CRP was assayed by turbidimetric assay using Beckman Coulter, model AU480 (250 S. Kraemer Blvd. Brea, CA 92821, USA). CRP values were divided into normal ( $<6 \mathrm{mg} / \mathrm{L}$ ), borderline $(6-10 \mathrm{mg} / \mathrm{L})$ and high $(>10 \mathrm{mg} / \mathrm{L}){ }^{25}$ CAG was done as per institutional protocol, and CAG was analyzed by 2 independent interventional cardiologists. CAD was classified on the basis of CAG findings: insignificant if stenosis is $<50 \%$ and significant if stenosis is $\geq 50 \%$; and single-vessel, double-vessel, triple-vessel disease and normal coronaries according to number of vessels involved.

Categorical variables were expressed as proportions (percentages) and numerical data were expressed as mean (standard deviation) and range. Chi square test was used to analyze the categorical variables, and Pearson's correlation coefficient was used to test the relationship between CRP and BMI in CAD patients. Statistical Package for the Social Sciences (SPSS) version 23.0 for Windows was used to analyze the data. $p$ values $<0.05$ were considered as statistically significant.

The study was approved by the Ethical Review Board of Dhaka Medical College. Written informed consent was provided by the participants. Data were collected and analyzed by the investigators.

\section{Results:}

In the present cross-sectional study, almost $2 / 3$ rds (65.0\%) of the patients belonged to age group 41-60 years. The mean age was $51.4 \pm 10.7$ years, ranging from 25-85 years. Majority $(82.3 \%)$ of the study patients were male. Among the risk factors, hypertension was the commonest (40.0\%), followed by DM (31.3\%), smoking (30.5\%), history of IHD (28.3\%) and dyslipidemia (22.6\%). Demographic characteristics like age, sex and educational status did not differ significantly between obese and non-obese patients. (Table I) Risk factors for CAD were similar between obese and non-obese, however, DM, hypertension and dyslipidaemia were significantly more common in obese group than in non-obese group. (Table 2). In the present study, raised CRP was significantly more common in obese than in non-obese patients $(56.9 \%$ vs. $47.9 \%, p=0.04$ ), (Table 3 ) and a significant positive correlation was found between CRP and BMI ( $r=0.228$; $\mathrm{p}=0.001$ ) (Figure 1). Again, risk factors for CAD were similar between high-CRP (>10 mg/L) and non-high CRP ( $\leq 10$ $\mathrm{mg} / \mathrm{L}$ ) groups, however, DM, hypertension and dyslipidaemia were significantly more common in highCRP group than in non-high CRP group. (Table 4) Triplevessel CAD was found significantly more commonly in obese group than in non-obese group $(29.3 \%$ vs $24.4 \%$, $\mathrm{p}=0.04)$. (Figure 2) Obesity, high CRP (>10 mg/L), DM, and high $\mathrm{HbA} 1 \mathrm{c}(\geq 6.5 \%)$ were found significant predictors of severe CAD $(p<0.5)$ in multivariate logistic regression analysis (Table V).

Most $(65.0 \%)$ of the patients belonged to age $41-60$ years. The mean age was found $51.4 \pm 10.7$ years with range

Table-I

Association between obesity and demographic characteristics $(N=668)$

\begin{tabular}{|c|c|c|c|}
\hline \multirow[t]{2}{*}{ Demographic characteristics } & \multicolumn{2}{|c|}{ Obesity } & \multirow[t]{2}{*}{$p$ value } \\
\hline & Yes $(n=58) n(\%)$ & No $(n=610) n(\%)$ & \\
\hline Mean age (years) & $49.8 \pm 12.0$ & $51.5 \pm 10.6$ & $0.249^{\text {ns }}$ \\
\hline Range (min-max) & 28-76 & $25-85$ & \\
\hline \multicolumn{4}{|l|}{ Sex } \\
\hline Male & $45(77.6)$ & $505(82.8)$ & $0.321^{\mathrm{ns}}$ \\
\hline Female & $13(22.4)$ & $105(17.2)$ & \\
\hline \multicolumn{4}{|l|}{ Educational status } \\
\hline Illiterate & $39(67.2)$ & $351(57.5)$ & \\
\hline Primary & $7(12.1)$ & $103(16.9)$ & \\
\hline Secondary & $5(8.6)$ & $106(17.4)$ & $0.261^{\mathrm{ns}}$ \\
\hline Higher & $4(6.9)$ & $33(5.4)$ & \\
\hline Graduate and above & $3(5.2)$ & $17(2.8)$ & \\
\hline
\end{tabular}

Data were analyzed by chi-square test and unpaired t-test, ns= not significant 
from $25-85$ years. Majority $(82.3 \%)$ patients were male and $390(58.4 \%)$ patients were illiterate. In risk factors, highest 267 (40.0\%) patients had hypertension followed by $209(31.3 \%)$ diabetes mellitus, 204 (30.5\%) smoker, $189(28.3 \%) \mathrm{H} / \mathrm{O}$ ischemic heart disease, 151 (22.6\%) dyslipidemia and $58(8.7 \%)$ obesity. Mean age was little bit lower in obese group than non obese $(49.8 \pm 12.0$ vs $51.5 \pm 10.6$ years), female patients were higher in obese group than non obese $(22.4 \%$ vs $17.2 \%)$ but these results were not statistically significant $(p>0.05)$ (Table I). Among the risk factors, diabetes mellitus, hypertension and dyslipidemia were found significantly higher in obese group than non obese (Table I). High CRP was found higher in obese than non obese (56.9\% vs $47.9 \%$ ) (Table III). Positive correlation $(r=0.228 ; p=0.001)$ was found between CRP and BMI (Figure 1). Among the risk factors, diabetes mellitus, hypertension and dyslipidemia were found significantly higher in high CRP group than normal and borderline group (Table IV). Triple vessel CAD was found significantly higher in obese group than non obese (29.3\% vs $24.4 \%$ ) and normal CAD was found significantly higher in non obese group than obese (Figure 2). Multi variable logistic regression was found high $\mathrm{HbA} 1 \mathrm{c}$, high $\mathrm{CRP}$, diabetes mellitus and obesity were statistically significant $(p<0.05)$ in severe CAD (Double and triple vessel) patient (Table V).

Table-II

Association between obesity with clinical risk factors $(n=668)$

\begin{tabular}{lccc}
\hline Risk factor & \multicolumn{2}{c}{ Obesity } & p value \\
\cline { 2 - 4 } & Yes $(\mathrm{n}=58) \mathrm{n}(\%)$ & No $(\mathrm{n}=610) \mathrm{n}(\%)$ & $0.001^{\mathrm{s}}$ \\
\hline Diabetes mellitus & $41(70.7)$ & $168(27.5)$ & $0.013^{\mathrm{s}}$ \\
Hypertension & $32(55.2)$ & $235(34.5)$ & $0.024^{\mathrm{s}}$ \\
Dyslipidemia & $20(34.5)$ & $131(21.5)$ & $0.200^{\mathrm{ns}}$ \\
Smoking & $22(37.9)$ & $182(29.8)$ & $0.163^{\mathrm{ns}}$ \\
Smokeless tobacco & $12(20.7)$ & $85(13.9)$ & $0.166^{\mathrm{ns}}$ \\
Alcohol & $1(1.7)$ & $1(0.2)$ & $0.121^{\mathrm{ns}}$ \\
Family history of CAD & $5(8.6)$ & $26(4.3)$ & $0.429^{\mathrm{ns}}$ \\
H/o ischemic heart & $19(32.8)$ & $170(27.9)$ & $9(1.5)$ \\
disease & & $9(1.5)$ & $0.246^{\mathrm{ns}}$ \\
Previous PTCA & $1(1.7)$ & & $0.599^{\mathrm{ns}}$ \\
Previous CABG & & & \\
\hline
\end{tabular}

Data were analyzed by chi-square test, $s=$ significant, ns= not significant

Table-III

Association between obesity and CRP of the study population ( $N=668$ )

\begin{tabular}{lccc}
\hline CRP & \multicolumn{2}{c}{ Obesity } & p value \\
\cline { 2 - 3 } & Yes $(\mathrm{n}=58) \mathrm{n}(\%)$ & No $(\mathrm{n}=610) \mathrm{n}(\%)$ & \\
\hline Normal $(<6 \mathrm{mg} / \mathrm{L})$ & $0(0.0)$ & $262(9.2)$ & $0.045^{\mathrm{s}}$ \\
Borderline $(6-10 \mathrm{mg} / \mathrm{L})$ & $25(43.1)$ & $292(47.9)$ & \\
High $(>10 \mathrm{mg} / \mathrm{L})$ & $33(56.9)$ & & \\
\hline
\end{tabular}

Data were analyzed by chi-square test, $\mathrm{s}=$ significant 


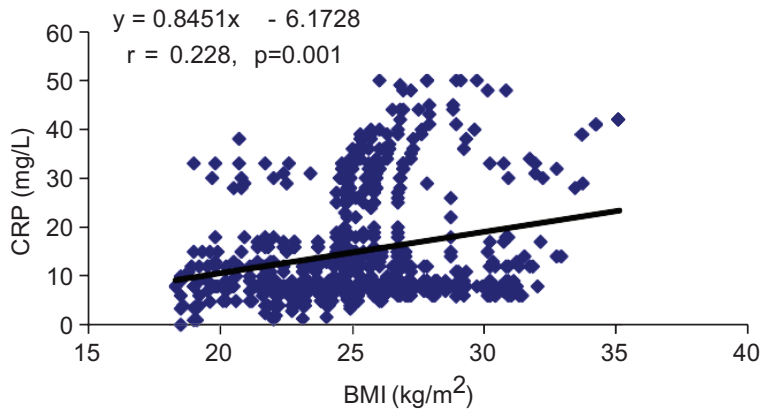

Fig.-1: Scatter diagram showing correlation between CRP and BMI.

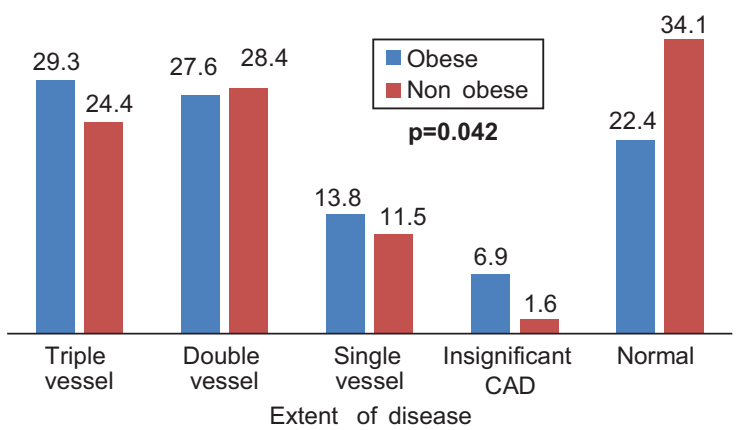

Fig.-2: Bar diagram showing obesity and extent of coronary artery disease of the study population

Table-IV

Association between CRP and clinical risk factors $(N=668)$

\begin{tabular}{lccc}
\hline Risk factor & \multicolumn{2}{c}{ CRP } & p value \\
\cline { 2 - 3 } & $\begin{array}{c}\text { High }(>10 \mathrm{mg} / \mathrm{L}) \\
(\mathrm{n}=325) \mathrm{n}(\%)\end{array}$ & $\begin{array}{c}\text { Not high }(\leq 10 \mathrm{mg} / \mathrm{L}) \\
(\mathrm{n}=343) \mathrm{n}(\%)\end{array}$ \\
\hline Diabetes mellitus & $149(45.8)$ & $60(17.5)$ & $0.001^{\mathrm{s}}$ \\
Hypertension & $146(51.1)$ & $121(29.4)$ & $0.011^{\mathrm{s}}$ \\
Dyslipidemia & $88(27.1)$ & $63(18.4)$ & $0.048^{\mathrm{s}}$ \\
Smoking & $101(31.1)$ & $103(30.0)$ & $0.769^{\mathrm{ns}}$ \\
Smokeless tobacco & $50(15.4)$ & $47(13.7)$ & $0.537^{\mathrm{ns}}$ \\
Alcohol & $1(0.3)$ & $1(0.3)$ & $0.737^{\mathrm{ns}}$ \\
Family history of CAD & $16(4.9)$ & $15(4.4)$ & $0.736^{\mathrm{ns}}$ \\
H/o ischemic heart disease & $99(30.5)$ & $50(26.2)$ & $0.226^{\mathrm{ns}}$ \\
Previous PTCA & $6(1.8)$ & $4(1.5)$ & $0.693^{\mathrm{ns}}$ \\
Previous CABG & $6(1.8)$ & & $0.343^{\mathrm{ns}}$ \\
\hline
\end{tabular}

Data were analyzed by chi-square test, $\mathrm{s}=$ significant, $\mathrm{ns}=$ not significant

Table-V

Multivariable logistic regression analysis for severe $C A D$

\begin{tabular}{|c|c|c|c|c|}
\hline & Adjusted & & & $P$ \\
\hline & OR & Lower & Upper & Value \\
\hline $\mathrm{HbA} 1 \mathrm{c}(\geq 6.5)$ & 0.261 & 0.025 & 0.882 & $0.023^{s}$ \\
\hline CRP (>10 mg/L) & 30.222 & 8.874 & 99.389 & $0.001^{\mathrm{s}}$ \\
\hline Diabetes mellitus & 0.103 & 0.011 & 0.953 & $0.045^{\mathrm{s}}$ \\
\hline Obesity & 0.396 & 0.195 & 0.967 & $0.048^{s}$ \\
\hline Hypertension & 1.059 & 0.268 & 4.181 & $0.935^{\mathrm{ns}}$ \\
\hline Dyslipidemia & 0.698 & 0.146 & 3.346 & $0.653^{n s}$ \\
\hline Smoking & 0.547 & 0.143 & 2.092 & $0.378^{n s}$ \\
\hline Constant & 0.007 & - & - & $0.001^{\mathrm{s}}$ \\
\hline
\end{tabular}

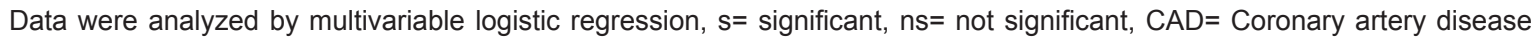

\section{Discussion:}

In the present cross-sectional study, almost $2 / 3$ rds $(65.0 \%)$ of the patients belonged to age group 41-60 years. The mean age was $51.4 \pm 10.7$ years, ranging from 25-85 years. Majority (82.3\%) of the study patients were male. Among the risk factors, hypertension was the commonest $(40.0 \%)$, followed by DM $(31.3 \%)$, smoking $(30.5 \%)$, history of IHD (28.3\%) and 
dyslipidemia (22.6\%). In the present study, 58 out of 668 patients were obese, hence the prevalence of obesity was $9.51 \%$, which is higher than the national prevalence of $4.6 \% .{ }^{23}$ This disparity is presumably due to the patients having clustering of CAD risk factors included in the study. Similar observation was found by Khan et al. ${ }^{26}$ Risk factors for CAD were similar between obese and non-obese, however, DM, hypertension and dyslipidaemia were significantly more common in obese group than in non-obese group. This is logical because risk factors of CAD tend to cluster together.

In the present study, raised CRP was significantly more common in obese than in non-obese patients $(56.9 \%$ vs. $47.9 \%, p=0.04)$, and a significant positive correlation was found between CRP and BMI $(r=0.228 ; p=0.001)$. A systematic review and meta-analysis involving various populations, obesity was associated with elevated levels of CRP and the association is stronger in women and North Americans/Europeans. ${ }^{27}$ Another meta-analysis found significant correlation between CRP and obesity in Chinese adults and children. ${ }^{28}$ Previously, in the study by Kao et al., higher BMI, as well as, central obesity were independently associated with higher levels of CRP. ${ }^{29}$ Also, in a Mediterranean population, CRP concentrations increased significantly with increasing cardiovascular risk factors. Men and women with metabolic syndrome showed significantly higher levels of CRP than their counterparts, even after adjustment for BMI and age. ${ }^{30}$ Again, risk factors for $C A D$ were similar between highCRP (>10 mg/L) and non-high CRP ( $\leq 10 \mathrm{mg} / \mathrm{L})$ groups, however, DM, hypertension and dyslipidaemia were significantly more common in high-CRP group than in non-high CRP group. In an international multicentre study of 13,874 patients, among underweight, normal weight, overweight, and obese individuals, there was increasing prevalence of diabetes (7 vs. $10 \%$ vs. 12 vs. $19 \%$ ), hypertension ( 37 vs. $40 \%$ vs. 46 vs. $59 \%$ ), and hyperlipidaemia ( 48 vs. $52 \%$ vs. 56 vs. $56 \%$; $P<0.001$ for trend). ${ }^{31}$ Other studies demonstrated positive association between DM and metabolic syndrome with CRP. ${ }^{32,33}$ Triple-vessel CAD was found significantly more commonly in obese group than in non-obese group $(29.3 \%$ vs $24.4 \%, p=0.04)$. These findings correlate well with those of Khan et al. depicting higher presence of triple-vessel disease in obese patients compared to the non-obese counterparts. ${ }^{26}$ In the present study, Obesity, high CRP (>10 mg/L), DM, and high HbA1c ( $\geq 6.5 \%$ ) were found significant predictors of severe CAD $(p<0.5)$ in multivariate logistic regression analysis. In the study by Labounty et al., higher BMI was independently associated with increased risk of myocardial infarction (hazards ratio: 1.28 per $+5 \mathrm{~kg} / \mathrm{m}(2), 95 \% \mathrm{Cl}: 1.12-1.45, \mathrm{P}<0.001) .{ }^{31}$
The study has got some limitations. This was a singlecentre study. No distinction was made between generalized and visceral obesity. Only CRP was evaluated as a marker of inflammation. Also, CAD severity in CAG was determined by visual assessment, hence, intar- and inter-observer variability could not be ruled out.

\section{Conclusion:}

Obesity is associated with raised CRP in patients with $C A D$, and a significant positive association exists between obesity and inflammation and CAD. Future studies are needed to explore the impact of type of obesity and inflammation on CAD. Also, role of lifestyle modification and pharmacological management in reducing obesity and inflammation in the context of CAD may be evaluated.

\section{Reference:}

1. Khan MA, Hashim MJ, Mustafa H, Baniyas MY, Al Suwaidi SKBM, AlKatheeri R, Alblooshi FMK, Almatrooshi MEAH, Alzaabi MEH, Al Darmaki RS, Lootah SNAH. Global Epidemiology of Ischemic Heart Disease: Results from the Global Burden of Disease Study. Cureus. 2020 Jul 23;12(7):e9349. doi: $10.7759 /$ cureus.9349.

2. Nowbar AN, Gitto M, Howard JP, Francis DP, AlLamee R. Mortality From Ischemic Heart Disease. Circ Cardiovasc Qual Outcomes. 2019 Jun;12(6):e005375. doi: 10.1161/CIRCOUTCOMES. 118.005375 .

3. World Health Organization. The top 10 causes of death. Available at: https://www.who.int/news-room/ fact-sheets/detail/the-top-10-causes-of-death, accessed 6 May 2021.

4. Malakar AK, Choudhury D, Halder B, Paul P, Uddin A, Chakraborty S. A review on coronary artery disease, its risk factors, and therapeutics. J Cell Physiol. 2019 Aug;234(10):16812-16823. doi: 10.1002/jcp.28350.

5. Poirier P, Giles TD, Bray GA, Hong Y, Stern JS, PiSunyer FX, Eckel RH; American Heart Association; Obesity Committee of the Council on Nutrition, Physical Activity, and Metabolism. Obesity and cardiovascular disease: pathophysiology, evaluation, and effect of weight loss: an update of the 1997 American Heart Association Scientific Statement on Obesity and Heart Disease from the Obesity Committee of the Council on Nutrition, Physical Activity, and Metabolism. Circulation. 2006 Feb 14;113(6):898-918. doi: 10.1161/ CIRCULATIONAHA.106.171016. 
6. Ng M, Fleming T, Robinson M, Thomson B, Graetz $\mathrm{N}$, Margono C, Mullany EC, Biryukov S, Abbafati C, Abera SF, Abraham JP, Abu-Rmeileh NM, Achoki T, AlBuhairan FS, Alemu ZA, Alfonso R, Ali MK, Ali R, Guzman NA, Ammar W, Anwari P, Banerjee A, Barquera S, Basu S, Bennett DA, Bhutta Z, Blore J, Cabral N, Nonato IC, Chang JC, Chowdhury R, Courville KJ, Criqui MH, Cundiff DK, Dabhadkar KC, Dandona L, Davis A, Dayama A, Dharmaratne SD, Ding EL, Durrani AM, Esteghamati A, Farzadfar F, Fay DF, Feigin VL, Flaxman A, Forouzanfar MH, Goto A, Green MA, Gupta R, Hafezi-Nejad N, Hankey GJ, Harewood HC, Havmoeller R, Hay S, Hernandez L, Husseini A, Idrisov BT, Ikeda N, Islami F, Jahangir $E$, Jassal SK, Jee SH, Jeffreys M, Jonas JB, Kabagambe EK, Khalifa SE, Kengne AP, Khader YS, Khang YH, Kim D, Kimokoti RW, Kinge JM, Kokubo Y, Kosen S, Kwan G, Lai T, Leinsalu M, Li Y, Liang X, Liu S, Logroscino G, Lotufo PA, Lu Y, Ma J, Mainoo NK, Mensah GA, Merriman TR, Mokdad AH, Moschandreas J, Naghavi M, Naheed A, Nand D, Narayan KM, Nelson EL, Neuhouser ML, Nisar MI, Ohkubo T, Oti SO, Pedroza A, Prabhakaran D, Roy N, Sampson U, Seo H, Sepanlou SG, Shibuya K, Shiri R, Shiue I, Singh GM, Singh JA, Skirbekk V, Stapelberg NJ, Sturua L, Sykes BL, Tobias M, Tran $B X$, Trasande L, Toyoshima H, van de Vijver S, Vasankari TJ, Veerman JL, Velasquez-Melendez G, Vlassov VV, Vollset SE, Vos T, Wang C, Wang X, Weiderpass E, Werdecker A, Wright JL, Yang YC, Yatsuya H, Yoon J, Yoon SJ, Zhao Y, Zhou M, Zhu S, Lopez AD, Murray CJ, Gakidou E. Global, regional, and national prevalence of overweight and obesity in children and adults during 1980-2013: a systematic analysis for the Global Burden of Disease Study 2013. Lancet. 2014 Aug 30;384(9945):766-81. doi: 10.1016/S01406736(14)60460-8. Epub 2014 May 29. Erratum in: Lancet. 2014 Aug 30;384(9945):746.

7. Gomes F, Telo DF, Souza HP, Nicolau JC, Halpern A, Serrano CV Jr. Obesity and coronary artery disease: role of vascular inflammation. Arq Bras Cardiol. 2010 Feb;94(2):255-61, 273-9, 260-6. English, Portuguese, Spanish. doi: 10.1590/s0066782x2010000200021.

8. Mazurek T, Zhang L, Zalewski A, Mannion JD, Diehl JT, Arafat H, Sarov-Blat L, O'Brien S, Keiper EA, Johnson AG, Martin J, Goldstein BJ, Shi Y. Human epicardial adipose tissue is a source of inflammatory mediators. Circulation. 2003 Nov
18;108(20):2460-6. doi: 10.1161/01.CIR. 0000099542.57313.C5.

9. Cheng $\mathrm{KH}$, Chu CS, Lee KT, Lin TH, Hsieh CC, Chiu CC, Voon WC, Sheu SH, Lai WT. Adipocytokines and proinflammatory mediators from abdominal and epicardial adipose tissue in patients with coronary artery disease. Int J Obes (Lond). 2008 Feb;32(2):268-74. doi: 10.1038/sj.ijo.0803726.

10. Fitzgibbons TP, Czech MP. Epicardial and perivascular adipose tissues and their influence on cardiovascular disease: basic mechanisms and clinical associations. J Am Heart Assoc. 2014 Mar 4;3(2):e000582. doi: 10.1161/JAHA.113.000582.

11. Wang Z, Nakayama T. Inflammation, a link between obesity and cardiovascular disease. Mediators Inflamm. 2010;2010:535918. doi: 10.1155/2010/ 535918.

12. Mathieu P, Poirier P, Pibarot P, Lemieux I, Després JP. Visceral obesity: the link among inflammation, hypertension, and cardiovascular disease. Hypertension. 2009 Apr;53(4):577-84. doi: 10.1161/ HYPERTENSIONAHA.108.110320.

13. Manson JE, Colditz GA, Stampfer MJ, Willett WC, Rosner B, Monson RR, Speizer FE, Hennekens CH. A prospective study of obesity and risk of coronary heart disease in women. N Engl J Med. 1990 Mar 29;322(13):882-9. doi: 10.1056/ NEJM199003293221303.

14. Manson JE, Willett WC, Stampfer MJ, Colditz GA, Hunter DJ, Hankinson SE, Hennekens $\mathrm{CH}$, Speizer FE. Body weight and mortality among women. N Engl J Med. 1995 Sep 14;333(11):677-85. doi: 10.1056/NEJM199509143331101.

15. Ni Mhurchu C, Rodgers A, Pan WH, Gu DF, Woodward M; Asia Pacific Cohort Studies Collaboration. Body mass index and cardiovascular disease in the Asia-Pacific Region: an overview of 33 cohorts involving 310000 participants. Int J Epidemiol. 2004 Aug;33(4):751-8. doi: 10.1093/ije/ dyh163.

16. Momiyama Y, Ohmori R, Fayad ZA, Kihara T, Tanaka $\mathrm{N}$, Kato R, Taniguchi H, Nagata M, Nakamura H, Ohsuzu F. Associations between plasma C-reactive protein levels and the severities of coronary and aortic atherosclerosis. J Atheroscler Thromb. 2010 May;17(5):460-7. doi: 10.5551/jat.2931.

17. van der Zee PM, Biró E, Trouw LA, Ko Y, de Winter RJ, Hack CE, Sturk A, Nieuwland R. C-reactive 
protein in myocardial infarction binds to circulating microparticles but is not associated with complement activation. Clin Immunol. 2010 Jun;135(3):490-5. doi: 10.1016/j.clim.2010.01.002.,

18. Emerging Risk Factors Collaboration, Kaptoge $\mathrm{S}$, Di Angelantonio E, Lowe G, Pepys MB, Thompson SG, Collins R, Danesh J. C-reactive protein concentration and risk of coronary heart disease, stroke, and mortality: an individual participant metaanalysis. Lancet. 2010 Jan 9;375(9709):132-40. doi: 10.1016/S0140-6736(09)61717-7.

19. Ouchi N, Kihara S, Funahashi T, Nakamura $T$, Nishida M, Kumada M, Okamoto Y, Ohashi K, Nagaretani H, Kishida K, Nishizawa H, Maeda N, Kobayashi H, Hiraoka H, Matsuzawa Y. Reciprocal association of $\mathrm{C}$-reactive protein with adiponectin in blood stream and adipose tissue. Circulation. 2003 Feb 11;107(5):671-4. doi: 10.1161/ 01.cir.0000055188.83694.b3.

20. Donges CE, Duffield R, Drinkwater EJ. Effects of resistance or aerobic exercise training on interleukin-6, C-reactive protein, and body composition. Med Sci Sports Exerc. 2010 Feb;42(2):304-13. doi: 10.1249/ MSS.0b013e3181b117ca.

21. Mann JJ, Payne JR, Shah T, Pennell DJ, Humphries SE, Montgomery HE. C-reactive protein gene variant and the human left ventricular growth response to exercise: data from The LARGE Heart Study. J Cardiovasc Pharmacol. 2010 Jan;55(1):26-9. doi: 10.1097/FJC.0b013e3181c37d2d.

22. Islam AK, Majumder AA. Coronary artery disease in Bangladesh: a review. Indian Heart J. 2013 JulAug;65(4):424-35. doi: 10.1016/j.ihj.2013.06.004.

23. Biswas T, Garnett SP, Pervin S, Rawal LB. The prevalence of underweight, overweight and obesity in Bangladeshi adults: Data from a national survey. PLoS One. 2017 May 16;12(5):e0177395. doi: 10.1371/journal.pone.0177395.

24. Poirier P, Giles TD, Bray GA, Hong Y, Stern JS, PiSunyer FX, Eckel RH. Obesity and cardiovascular disease: pathophysiology, evaluation, and effect of weight loss. Arterioscler Thromb Vasc Biol. 2006 May;26(5):968-76. doi: 10.1161/ 01.ATV.0000216787.85457.f3.

25. Laakso M. Glycemic control and the risk for coronary heart disease in patients with non-insulindependent diabetes mellitus. The Finnish studies.
Ann Intern Med. 1996 Jan 1;124(1 Pt 2):127-30. doi: 10.7326/0003-4819-124-1_part_2-19960101100009.

26. Khan SB, Noor L, Hafiz-ur-Rehman, Hameedullah, Hafeezullah M, Awan ZA, Shahab ud Din, Shah SS. Prevalence of hypertension among obese and nonobese patients with coronary artery disease. J Ayub Med Coll Abbottabad. 2010 Apr-Jun;22(2):130-3.

27. Choi J, Joseph L, Pilote L. Obesity and C-reactive protein in various populations: a systematic review and meta-analysis. Obes Rev. 2013 Mar; 14(3):23244. doi: 10.1111/obr.12003.

28. Zhao Y, Lv G. Correlation of C-reactive protein level and obesity in Chinese adults and children: a metaanalysis. J Endocrinol Invest. 2013 Sep;36(8):6427. doi: $10.3275 / 9004$.

29. Kao TW, Lu IS, Liao KC, Lai HY, Loh CH, Kuo HK. Associations between body mass index and serum levels of C-reactive protein. S Afr Med J. 2009 May;99(5):326-30.

30. García-Lorda P, Bulló M, Balanzà R, Salas-Salvadó J. C-reactive protein, adiposity and cardiovascular risk factors in a Mediterranean population. Int $\mathrm{J}$ Obes (Lond). 2006 Mar;30(3):468-74. doi: 10.1038/ sj.ijo. 0803182 .

31. Labounty TM, Gomez MJ, Achenbach S, Al-Mallah M, Berman DS, Budoff MJ, Cademartiri F, Callister $T Q$, Chang HJ, Cheng V, Chinnaiyan KM, Chow B, Cury R, Delago A, Dunning A, Feuchtner G, Hadamitzky M, Hausleiter J, Kaufmann P, Kim YJ, Leipsic J, Lin FY, Maffei E, Raff G, Shaw LJ, Villines TC, Min JK. Body mass index and the prevalence, severity, and risk of coronary artery disease: an international multicentre study of 13,874 patients. Eur Heart J Cardiovasc Imaging. 2013 May;14(5):456-63. doi: 10.1093/ehjci/jes179.

32. Gurven MD, Trumble BC, Stieglitz J, Blackwell AD, Michalik DE, Finch CE, Kaplan HS. Cardiovascular disease and type 2 diabetes in evolutionary perspective: a critical role for helminths? Evol Med Public Health. 2016 Jan;2016(1):338-357. doi: 10.1093/emph/eow028.

33. Martín-Timón I, Sevillano-Collantes C, SeguraGalindo A, Del Cañizo-Gómez FJ. Type 2 diabetes and cardiovascular disease: Have all risk factors the same strength? World J Diabetes. 2014 Aug 15;5(4):444-70. doi: 10.4239/wjd.v5.i4.444. 